\title{
Nanjoak Umoah: Upacara Adat Penyembuhan Luka Bakar di Desa Pulau Tengah Kerinci
}

\author{
Andrianus Andrianus ${ }^{1}$, Erda Fitriani $i^{2}$, Delmira Syafrini ${ }^{3}$ \\ ${ }^{1,2,3}$ Universitas Negeri Padang \\ Email: andrianus131@gmail.com, fitriani_cim@fis.unp.ac.id
}

\begin{abstract}
Abstrak
Artikel ini bertujuan untuk menjelaskan makna dari upacara Nanjoak Umoh di Desa Pulau Tengah Kecamatan Keliling Danau Kabupaten Kerinci. Penelitian ini dianalisis dengan teori interpretativisme simbolik oleh Clifford Geertz. Penelitian ini merupakan penelitian kualitatif dengan jenis penelitian etnografi. Pemilihan informan secara purposive sampling sebanyak 29 orang. Pengumpulan data dilakukan dengan wawancara mendalam, dan observasi partisipasi, dianalisis dengan model interaktif. Hasil penelitian mengungkapkan makna Upacara Nanjoak umoh di desa Pulau Tengah Kecamatan Keliling Danau Kabupaten Kerinci secara emik yaitu (1) menghukum orang dan keluarga korban luka bakar atas kelalaiannya, (2) sebagai wujud maaf kapada seluruh para pengurus adat Desa Pulau Tengah dan kepada masyarakat sekitar tempat tinggalnya, (3) untuk meminta do'a kesembuhan kepada seluruh peserta upacara tradisi Nanjoak Umoh. Selain dari itu juga peneliti menemukan makna Nanjoak Umoh secara Etik yaitu adanya (1) Keyakinan bahwa Nanjoak Umoh obat yang ampuh menyembuhkan luka bakar;(2) Sebagai pembelajaran; (3) Memperkuat Solidaritas Sosial; (4) Menunjukkan Identitas.
\end{abstract}

Kata Kunci: Interpretivisme Simbolik, Nanjoak Umoh, Upacara, Penyembuhan Luka Bakar

\begin{abstract}
This article aims to explain the meaning of the ceremony Nanjoak Umoh in Middle Island Village District of Keliling Danau Kerinci. This study analyzed the theory of symbolic interpretativisme by Clifford Geertz. This study is a qualitative research with this type of ethnographic research. Selection of informants in purposive sampling as many as 29 people. The data collection is done by in-depth interviews and participatory observation, analyzed by an interactive model. This research reveals the meaning Ceremony Nanjoak Umoh in the village of Middle Island District of Keliling Danau Kerinci in emik namely (1) to punish people and families of victims of burns, (2) as a form of apology kapada across the traditional authorities Village Middle Island to the negligence and to the surrounding community, (3) to ask for prayers of healing to all participants of the ceremony tradition. Umoh Nanjoak Apart from that the researchers also found meaning Nanjoak Umoh in Ethicsnamely the (1) The belief that Nanjoak Umoh powerful drugs heal burns (2) As a learning (3) Strengthen Social solidarity (4) Shows Identity.
\end{abstract}

Keywords: Interpretisvisme Symbolic, Nanjoak Umoh, Ceremony, Healing Burns

\begin{tabular}{l|l|l} 
Received: June 15, 2020 & Revised: June 29, 2020 & Published: June 30, 2020
\end{tabular}

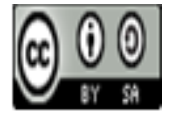




\section{Pendahuluan}

Manusia melaksanakan berbagai upacara pada waktu-waktu tertentu dalam hidupnya. Upacara tersebut seperti upacara perkawinan, upacara kematian upacara siap panen, upacara tolak bala dan lain sebagainya. Berbagai macam bentuk upacara yang dilakukan oleh masyarakat dalam memperingati peristiwa-peristiwa penting dalam hidupnya, mereka percaya bahwa adanya semacam kekuatan-kekuatan di luar kemampuan mereka yang mempengaruhi kehidupan mereka. Sebagian besar suku bangsa di Indonesia melaksanakan berbagai macam bentuk upacara tradisional. Berbagai bentuk dan corak yang dilakukan dalam pelaksanaan upacara tersebut, mulai dari yang profan sampai ke hal-hal yang bernuansa sakral.

Salah satu upacara tradisional tersebut dapat ditemui pada masyarakat Desa Pulau Tengah Kecamatan Keliling Danau, Kerinci, Jambi yang dikenal dengan istilah Nanjoak Umoh. Nanjoak Umoh adalah tradisi masyarakat Desa Pulau Tengah sebagai obat tradisional untuk menyembuhkan luka bakar yang diderita agar bisa mendingin, mengering dan sembuh, karena menurut kepercayaan masyarakat Desa Pulau Tengah apabila salah seorang anak buah Rajo Pati, Parano mantri, Pemangku tigo puluh mendapat musibah luka bakar maka untuk menyembuhkan luka bakar, dan menghilangkan rasa panas maka diadakannya upacara tradisi Nanjoak Umoh. Walaupun sudah ada pengobatan moderen di Desa Pulau Tengah seperti Puskesmas, namun dari itu bukan berarti masyarakat Desa Pulau Tengah tidak mempercayai ilmu kesehatan moderen, bahkan mereka mengatahui bagaimana cara kerjanya pengobatan moderen dalam menyembuhkan luka bakar itu yaitu seperti berdasarkan pengetahuan, bukti klinis dan pengkajian ilmiah yang mendalam, seperti menurut ilmu kesehatan moderen obat yang ampuh untuk mengobati luka bakar yang diderita itu bisa dengan menggunakan air dingin atau es untuk mengurangi rasa panas yang diderita kemudian salap atau krim yang dioleskan ke luka tersebut agar luka bakar itu bisa bisa sembuh, dan hal itu sudah mereka lakukan untuk menyembuhkan luka tersebut tetapi mereka merasa luka yang diderita itu tidak bisa sembuh jikalau mereka belum melakukan upacara Nanjoak Umoh ini.

Upacara Najoak Umoh dulunya dipercayai sebagai obat adat atau mengobati dengan aturan adat Desa Pulau Tengah. Pada zaman sekarang ini rumah yang terbuat dari kayu itu mulai barkurang karena kebanyakan masyarakat Desa Pulau tengah merobohkan rumahnya yang terbuat dari kayu itu dan menggantikannya dengan rumahnya dengan rumah yang menggunakan bahan dasar semen dan memiliki banyak kaca guna untuk mempercantik rumah mereka itu. Hal tersebut bukan merupakan hal yang sangat fatal sehingga bisa menghilangkan upacara Nanjoak Umoh karena buktinya sampai sekarang upacara Nanjoak Umoh masih tetap dilaksanakan akan tetapi sudah mengalami suatu modifikasi yang mana rumah yang akan di tombak itu terdapat kaca maka mereka boleh menutupinya dengan menggunakan atap seng, kayu dan lain sebagainya.

Pelaksanaan upacara tradisi Nanjoak Umoh tidak ada tanggal dan bulan yang pasti kapan proses pelaksanaannya, yang menjadi patokannya adalah apabila ada laporan dari salah seorang warga Desa Pulau Tengah, kepada pengurus adat bahwa telah terjadi musibah luka bakar. Korban yang terkena luka bakar itulah yang melaporkan kepada salah seorang pengurus adat Desa Pulau Tengah yang bergelar Cerdik pandai.

Nanjoak Umoh penuh dengan muatan upacara dan ritual, seperti dalam proses acaranya tidak sembarangan orang yang memimpin upacara Nanjoak Umoh ini itu harus dari pengurus adat Desa Pulau Tengah yaitu Depati Ninik Mamak, namun yang menjadi peserta upacara ini ialah para sanak/famili dari korban luka bakar, para masyarakat sekitar tempat tinggal korban luka bakar dan juga tamu undangan yang sangaja diundang oleh pihak tuan rumah. selanjutnya yang memimpin para peserta upacara Nanjoak Umoh ini juga harus dari pengurus adat Desa Pulau Tengah yang dinamai Cerdik Pandai. sirih seperantang dan uang meh terang (uang koin). 
Dalam proses pelaksanaannya, Cerdik Pandai beserta rombongan pergi menjauhkan diri sekitar 50 meter dari rumah yang akan ditombak itu sambil memegang batang puar kamudian mereka mendekati pula rumah itu, setelah mendekat Cerdik Pandai membacakan sebuah mantra ke arah rumah yang akan ditombak itu.

Selanjutnya, seluruh peserta rebutan untuk mengambil karung sehingga acara di luar rumah yang berkaitan dengan upacara Nanjoak Umoh telah selesai dilakukan, kemudian seluruh peserta dipersilakan untuk masuk ke rumah untuk melakukan ritual menyembui/penyemburan dengan kunyit ke luka bakar yang diderita, acara ini dipimpin juga oleh Depati Ninik Mamak, dan langsung melakukan penyemburan pertama ke luka bakar yang diderita itu kemudian disusul oleh peserta lainnya, kemudian pembacaan do'a oleh Alim Ulamo Desa Pulau Tengah, terakhir acara pno atau pidato adat, selanjutnya diiringi dengan acara makan bersama untuk semua yang menghadiri acara upacara tradisi Nanjoak Umoh ini, dan pemberian upeti oleh pihak tuan rumah kepada para pengurus adat Desa Pulau Tengah.

Adapun gambaran luka bakar yang sering diupacarakan dalam upacara Nanjoak Umoh adalah bagian yang terkena lebih dalam dari permukaan kulit, rasa panas dan nyeri lebih hebat, selain kemerahan juga timbul gelembung yang berisi cairan, tampak ada jaringan yang mati (kehitaman). Hal yang perlu juga diperhatikan selain kedalaman luka bakar juga luas permukaan kulit yang terkena trauma panas. Semakin luas permukaan kulit yang terkena semakin membahayakan jiwa korban. Luka tersebut tidak mesti disebabkan karena terkena api saja, melainkan juga terkena benda panas atau juga terkena sengatan listrik dan lain sebagainya.

Sejauh ini belum ada penelitian mengenai upacara nanjoak umoh di Desa Pulau Tengah Kecamatan Keliling Danau. Beberapa penelitian yang sudah ada mengenai upacara penyembuhan yaitu (Reni, 2006); dan (Asmawati, Hartati, \& Emawati, 2018). Oleh karena itu maka penelitian ini akan mengungkap makna upacara Nanjoak Umoh bagi masyarakat di Desa Pulau Tengah. Dalam upacara Nanjoak Umoh ini memiliki simbol-simbol dengan simbol-simbol tersebut memiliki makna yang hanya dipahami oleh masyarakat setempat.

\section{Metode Penelitian}

Penelitian ini dilakukan di Desa Pulau Tengah Kecamatan Keliling Danau Kabupaten Kerinci. Penelitian ini dilakukan dengan pendekatan kualitatif dengan tipe penelitian etnografi. Teknik pengambilan informan yaitu dengan purposive sampling, artinya peneliti menentukan sendiri kriteria informan penelitian (Bungin, 2003). Adapun kriteria informan dalam penelitian ini adalah: Kriteria-kriteria dan pertimbangan dalam penentuan informan di atas, tertuju pada (1) orang yang pernah mengikuti tradisi Nanjoak Umoh. (2) para tokoh masyarakat yang mengetahui tradisi Nanjoak Umoh. (3) Depati Ninik Mamak Desa Pulau Tengah serta pengurus dasa Pulau Tengah yang lainnya yang pernah memimpin acara tradisi Nanjoak Umoh ini. Pengumpulan data dilakukan dengan observasi pertisipasi, dan wawancara mendalam (Lexy, 1994). Observasi yang peneliti lakukan adalah observasi aktif, artinya adalah peneliti terlibat langsung di lokasi saat aktivitas upacara Nanjoak Umoh dilakukan. Analisis data dilakukan sejak awal penelitian dilaksanakan, karena yang diteliti adalah proses maupun produk dari proses. Untuk itu, dalam pengumpulan data selalu dilengkapi dengan pembuatan catatan lapangan (Sugiyono, 2010).

\section{Hasil dan Pembahasan}

\section{Simbol dan Makna Benda yang Dipakai dalam Upacara Nanjoak Umoh secara Emik.}

\section{Batang puo/puar sebagai alat penombak}

Batang Puar adalah batang yang berwarna hijau dan di akarnya bisa dijadikan rempahrempah, batang puar biasa tumbuh di ladang yang tempat yang lembab atau berair dan tingginya 
berkisar antara 2-3 meter. Menurut pandangan Geertz dalam teori intepretivisme simbolik ia mengatakan simbol adalah objek, kejadian, bunyi bicara, atau bentuk-bentuk tertulis yang diberi makna oleh manusia (Geertz, 1992). Sama halnya dengan batang puar yang menjadi sebuah objek sebagai obat untuk menyembuhkan luka bakar itu. Masyarakat memaknai bahwa untuk mendinginkan luka bakar yang diderta itu harus menggunakan batang puar sebagai alat untuk menombak rumah dalam upacara Nanjoak Umoh.

\section{Beras segenggam, isi kemiri, kunyit, benang putih, merah dan hitam cicin anyir.}

Beras segenggam adalah beras dengan jumlah segenggam tangan orang dewasa, Isi kemiri adalah kemiri yang dipecahkan kemudian diambil isinya sebanyak dua buah kemiri, Kunyit yang sengaja dikupas kulitnya dan dipotong kecil-kecil, benang putih, merah dan hitam digunakan untuk mengikat cincin anyya yang dibuat menjadi gelang dan diikat ditangan si sakit. Beras segenggam, Isi kemiri, kunyit dalam upacara Nanjoak Umoh mengandung makna didalamnya. Makna dari beras segenggam, isi kemiri, kunyit yang merupakan sebuah benda sebagai obat untuk mempercepat agar luka tersebut tidak berair dan mengering.

\section{Uang pampas}

Uang Pampas adalah uang yang diletakkan bersamaan dengan alat untuk menyembur luka bakar itu, yang sengaja disiapkan oleh tuan rumah sendiri kemudian diberikan ke pengurus adat untuk diberikan kepada korban luka bakar dan jumlahnya tidak ditentukan. Uang pampas ini tidak bisa ditinggalkan dalam upacara Nanjoak Umoh. Uang pampas yang merupakan sebuah benda sebagai penghibur si sakit. Masyarakat memaknai bahwa untuk menghibur si sakit agar tidak memikirkan musibah yang lagi dideritanya harus menggunakan uang pampas dalam upacara Nanjoak Umoh.

Karung Kecil yang berisi sirih seperantang (sirih, kapa, tembakau, pinang, gambir, rokok yang terbuat dari daun enau) dan uang meh terang

Karung kecil ini adalah karung yang terbuat dari daun pandan yang dianyam sedemikian rupa yang digunakan setelah upacara Nanjoak Umoh/menombak rumah yang baru selesai ditombak, kemudian sengaja dilemparkan oleh keluarga korban luka bakar kepada peserta Nanjoak Umoh. Di dalam Karung kecil berisikan sirih seperantang (sirih, kapa, tembakau, pinang, gambir, rokok yang terbuat dari daun enau) dan uang meh terang. Alat tersebut di atas harus disiapkan oleh tuan rumah karena sudah menjadi aturan adat jikalau ada membuat hajatan harus menyiapkan alat tersebut, kemudian uang meh tarang adalah berupa uang receh yang juga disiapkan oleh tuan rumah penyelenggara acara upacara Najoak Umoh yang nantinya akan dilemparkan kepada masyarakat yang menghadiri upacara Najoak Umoh untuk diperebutkan dalam bentuk karung kecil gunanya untuk menghibur masyarakat yang mengikuti upacara Najoak Umoh ini agar tidak menegangkan suasana.

\section{Simbol dan Makna yang terdapat dalam aktivitas upacara Nanjoak Umoh secara Emik.}

\section{Menanjoak umoh/menombak rumah.}

Nanjoak Umoh yang dilakukan dalam upacara ini yaitu dengan tiga kali bolak balik dari jauh ke arah rumah yang akan di tombak itu dan mempersilahkan orang untuk menombak rumah kita. Kegiatan tersebut mengandung makna.Kegiatan tersebut juga memiliki mantra, yang isinya mengandung makna ialah suatu teguran keras kepada si sakit dan keluarga dari si sakit, mengandung makna bahwa kesalahan adat harus dibalas dengan hukuman adat pula. Seterusnya meminta di do'a kan oleh seluruh masyarakat yang menghadiri kepada Sang Pencipta Alloh Subhanawata'ala sehingga yang panas minta bisa didinginkan dan yang dingin minta bisa disejukkan sehingga mendapatkan suatu kesembuhan terhadap luka bakar yang di derita itu. 
Menurut pandangan Gertz dalam teori interpretivisme simbolik ia mengemukakan dalam defenisi kebudayaan salah satunya sebagai suatu sistem keteraturan dari makna dan simbolsimbol, yang dengan makna dan simbol tersebut individu-individu mendefenisikan dunia mereka, mengekspresikan perasaan-perasaan mereka, dan membuat penilaian mereka. Sejalan dari itu aktivitas dalam upacara Nanjoak Umoh pada masyarakat Desa Pulau Tengah dimaknai sebagai teguran keras, dan permohonan maaf serta meminta obat adat untuk luka bakar yang diderita si korban luka bakar itu (Geertz, 1992).

\section{Pelemparan Karung Kecil Yang Terbuat Dari Daun Pandan ke Arah Peserta Nanjoak Umoh.}

Pelemparan karung kecil ke arah masyarakat yang menghadiri acara ini juga termasuk aktivitas, dalam aktivitas ini masyarakat saling rebutan untuk mengambil karung kecil itu yang dilakukan dalam upacara tradisi Nanjoak Umoh. Pelemparan karung kecil yang berisi sirih seperantang uang meh terang ini dilempar oleh keluarga si sakit ke arah masyarakat ikut serta dalam upacara tersebut. Sejalan dari itu aktivitas pelemparan karung kecil oleh tuan rumah kepada seluruh peserta upacara Nanjoak Umoh pada masyarakat Desa Pulau Tengah dimaknai pemberian hadiah dan hiburan untuk masyarakat yang menghadiri upacara Nanjoak Umoh.

\section{Nyembuil menyembur}

Menyembur juga termasuk aktivitas yang dilakukan dalam upacara tradisi Nanjoak Umoh. Menyembur adalah proses mengunyah beras, isi kemiri, kunyit secara bersamaan kemudian disembur ke luka bakar tersebut. Nyembui/ Menyembur dalam upacara Nanjoak Umoh memiliki makna i di dalamnya. Aktivitas Menyembur ini dalam upacara Nanjoak Umoh pada masyarakat Desa Pulau Tengah dimaknai untuk meminta obat kepada orang yang menyembur luka bakar itu dalam upacara Nanjoak Umoh.

\section{Pemberian upeti oleh tuan rumah kepada pengurus adat Desa Pulau Tengah}

Upeti adalah harta yang diberikan suatu pihak ke pihak lainnya, sebagai tanda ketundukan dan kesetiaan, atau kadang-kadang sebagai tanda hormat. Pemberian upeti termasuk aktivitas yang dilakukan dalam upacara Nanjoak Umoh. Upeti yang diberikan bisa berupa rokok, buahbuahan dan lain sebagainya tidak ditentukan oleh adat. Upeti ini sengaja dikasih oleh pihak tuan rumah luka bakar, untuk para pengurus adat Desa Pulau Tengah. pemberian upeti dalam upacara Nanjoak Umoh memiliki makna tersendiri didalamnya. Aktivitas Pemberian upeti ini dalam upacara Nanjoak Umoh pada masyarakat Desa Pulau Tengah dimaknai ucapan terimakasih dan merupakan hadiah untuk para pengurus adat Desa Pulau tengah dalam upacara Nanjoak Umoh.

\section{Pno/Penyempaian Kata-Kata}

Bapeno adalah semacam pidato adat yang artinya pihak-pihak yang berbicara atau berdialog mempersembahkan kata-katanya dengan penuh hormat, dan dijawab dengan cara yang penuh hormat pula. Untuk itu digunakan suatu varian Bahasa tertentu, yang mempunyai format baku. Format bahasa pasambahan ini penuh dengan kata-kata klasik, pepatah-petitih dan dapat pula dihiasi pula dengan pantun-pantun. Bahasa pasambahan ini dapat berbeda dalam variasi dan penggunaan kata-katanya.

Pno termasuk aktivitas yang dilakukan dalam upacara Nanjoak Umoh. Dalam upacara Nanjoak Umoh pno disampaikan terlabih dahulu oleh oleh pihak tuan rumah penyeleggara upacara Nanjoak Umoh kepada para pengurus adat desa Pulau Tengah bahwa upacara Nanjoak Umoh, telah selesai dilaksanakan, kemudian dijawab oleh pihak pengurus adat Desa Pulau Tengah yang bergelar Ninik Mamak. pno mengandung makna dalam upacara Nanjoak Umoh.

Tujuan dari kegiatan pno mengatakan kata yang bersambungan untuk menyampaikan keinginan dengan kata-kata klasik, pepatah-petitih dan dapat pula dihiasi pula dengan pantunpantun, jadi masyarakat harus mengambil pesan dari setiap kegiatan yang telah dilakukan atau 
yang akan dilakukan. Acara pno ini sudah diartikan oleh masyarakat sebagai penyampaian seluruh pesan dari awal acara sampai akhir acara adat Desa Pulau Tengah dalam upacara Nanjoak Umoh.

\section{Makna Simbol Upacara Nanjoak Umoh Secara Etik}

Menurut pandangan Geertz dalam teori intepretivisme simbolik ia mengatakan simbol adalah objek, kejadian, bunyi bicara, atau bentuk-bentuk tertulis yang diberi makna oleh manusia. Dalam Nanjoak Umoh, menurut teori teori intepretivisme simbolik terdapat makna secara etik yang diasumsikan oleh peneliti. Jadi dalam penelitian tentang upacara Nanjoak Umoh peneliti melihat makna secara etik yaitu, keyakinan bahwa upacara nanjoak umoh bisa menyembuhkan luka bakar, rasa solidaritas sosial, dan untuk menunjukan identitas (Zakaria, 1984). Berikut makna secara etik dalam upacara Nanjoak Umoh.

\section{Keyakinan Bahwa Upacara Nanjoak Umoh Bisa Menyembuhkan Luka Bakar}

Adanya Sugesti. Sugesti ialah pengaruh psikis, baik yang datang dari diri sendiri, maupun yang datang dari orang lain, yang pada umumnya diterima tanpa adanya kritik dari individu yang bersangkutan. Sugesti akan mudah diterima orang lain, bila pada orang yang bersangkutan telah ada pendapat yang mendahului yang searah (Jong, 2000). Bila dalam diri orang ada pendapat yang telah mendahului dan searah dengan yang disugestikan maka umumnya orang akan mudah menerima pendapat tersebut.

Kepercayaan masyarakat terhadap upacara Nanjoak Umoh juga tidak lepas dari pengaruh sugesti dari luar dan dalam diri mereka yang mana dalam upacara Nanjoak Umoh terdapat ciri khas, seperti batang puar, beras segenggam, isi kemiri, kunyit dan uang, serta makanan yang dihidangkan yang merupakan alat yang digunakan dalam acara tersebut, itu merupakan alat yang telah ditentukan oleh adat dan diikuti sampai sekarang oleh masyarakat Desa Pulau Tengah maka dari itu mereka sudah lama mendapatkan sugesti tersebut bahwa untuk menyembuhkan luka bakar yang diderita oleh salah satu dari masyarakat Desa Pulau Tengah harus dengan upacara Nanjoak Umoh.

Masyarakat telah menganggap upacara Nanjoak Umoh ini yang dilakukan di Desa Pulau Tengah sebagai obat yang ampuh untuk mengobati luka bakar yang diderita itu, dan dapat di lihat dengan adanya orang dari Desa Pulau Tengah yang telah merantau segera untuk pulang karena di mau mengobati luka bakar yang didapatinya itu di tempat perantauannya karena dalam pikirannya atau masyarakat Desa Pulau Tengah luka bakar itu tidak akan sembuh jikalau belum melakukan upacara Nanjoak umoh ini. Kemudian dalam pikiran masyarakat Desa Pulau Tengah luka yang diderita itu akan lebih cepat sembuh itu merupakan suatu segesti yang telah meraka tanam dari zaman dahulu sampai sekarang, sehingga berbeda hasilnya jikalau ada salah satu masyarakat Desa Pulau Tengah yang terkena luka bakar yang parah dan belum melakukan upacara Nanjoak Umoh maka persepsi yang didapat dari pengaruh sugesti yang dari luar dan dalam tubuh mereka, maka luka itu sulit untuk disembuhkan bahkan tidak akan sembuh.

\section{Sebagai Pembelajaran.}

Ada banyak cara manusia dibuat sadar, atau terlebih membuat mereka tersadar akan apa yang diperbuatnya baik sengaja ataupun tidak sengaja yang menimbulkan dampak buruk bagi orang/masyarakat sekitarnya, akan tetapi tentu dengan cara-cara itu yang terpenting adalah pesannya tersampai kepada pelaku yang ditujukan kemudian hal itu menjadi suatu pembelajaran atas apapun peristiwa yang sedang dihadapinya sehingga menjadi dampak yang positif .

Dalam upacara Nanjaok Umoh menunjukan pesan kehati-hatian dan kewaspadaan dalam kehidupan sehari-hari dan dalam pergaulan/bermasyarakat sehingga tidak usah mengundang orang untuk merusak rumah/menombak rumah karena diundang untuk menebus kesalahan itu. Kegiatan upacara Nanjoak Umoh juga terdapat makna suatu penilaian agar selalu berhati-hati dan 


\section{Andrianus Andrianus, Erda Fitriani, Delmira Syafrini \\ Nanjoak Umoah: Upacara Adat Penyembuhan Luka Bakar di Desa Pulau Tengah Kerinci}

tetap waspada dalam melakukan suatu aktivitas yang berhubungan dengan api/benda panas lainnya.

\section{Solidaritas Sosial}

Dalam artian umumnya solidaritas merupakan kekuatan persatuan internal dari suatu kelompok. Masyarakat tradisional sebagai solidaritas mekanik yang tergantung pada "keseragaman" anggota-angotanya, yang mana dalam kehidupan bersamanya diciptakan bagi keyakinan dan nilai-nilai bersama. Dalam kondisi solidaritas individualitas tak berlaku sebab kesadaran individual tergantung pada kolektif dan mengikuti pada geraknya (Layendecker, 1983).

Sama hal nya dengan upacara Nanjoak Umoh, adanya solidaritas dari masyarakat ketika dalam pelaksanaan upacara Nanjoak Umoh tersebut. Seperti dalam membantu untuk mencarikan alat dalam upacara ini seperti alat untuk menombak rumah/ batang puar, dan perlengkapan lainnya hal ini terlihat sebelum dimulainya upacara Nanjoak Umoh dimana masyarakat saling tolong menolong seperti memasak nasi, serta hal yang berhubungan dalam lancarnya upacara Nanjoak Umoh. Kemudian dalam proses acaranya mereka bersedia untuk mengunyah alat menyembur sedangkan mereka tidak menyukai hal itu, namun demi membantu sesama masyarakat Desa Pulau Tengah mereka bersedia untuk mengunyahnya.

\section{Menunjukan Identitas}

Identitas seseorang merupakan sebuah status yang didapatkan dari orang lain, dan status biasanya didefenisikan sebagai suatu peringkat atau posisi seseorang dalam suatu kelompok (Pals, 2001). Anggota masyarakat melihat identitas dan status dari orang yang menghadiri upacara nanjoak umoh dalam setiap aktivitas dalam upacara nanjoak umoh terdapat pembagian tugas tersendiri didalamnya seperti Depati, Ninik Mamak,Cerdik Pandai, Alim Ulamo dan perangkat adat lainnya. Segala sesuatu yang berhubungan dengan waktu pelaksanaan, perlengkapan, dan bentuk acara orang-orang tersebutlah yang mengaturnya, seperti Ninik Mamak lah yang menjadi pemimpin upacara Nanjoak Umoh nantinya. Ninik Mamak juga selalu berdampingan dengan Depati, dan Cerdik Pandai bertugas dalam memimpin para peserta/masyarakat biasa dalam Nanjoak Umoh nantinya, seterusnya yang memimpin do'a dipercayakan kepada tokoh agama/pegawai mesjid.

\section{Kesimpulan}

Berdasarkan penelitian ditemukan upacara Nanjaok Umoh memiliki Makna agar luka bakar yang diderita oleh salah satu warga Desa Pulau Tengah cepat sembuh di samping itu juga untuk (1) menghukum orang dan keluarga korban luka bakar atas kelalaiannya sehingga mengakibatkan terjadinya luka bakar itu, (2) sebagai wujud maaf kapada seluruh para pengurus adat Desa Pulau Tengah atas kelalaiannya dan kepada masyarakat sekitar tempat tinggalnya karena telah membuat suatu keributan di sekitar tempat tinggal mereka, (3) untuk meminta do'a kesembuhan kepada seluruh peserta upacara tradisi Nanjoak Umoh.

Peneliti juga menemukan 3 faktor yang mendukung upacara Nanjoak Umoh ini sehingga membuat upacara Nanjoak Umoh masih dipertahankan dalam masyarakat Desa Pulau Tengah yaitu (1)Keyakinan bahwa upacara nanjoak umoh bisa menyembuhkan luka bakar (2) sebagai suatu pembelajaran (3) Adanya solidaritas sosial antar masyarakat sehingga menjadikan jembatan silaturahmi dan menampakkan solidaritas antara sesama keluarga, dan para pengurus adat desa Pulau Tengah (4) sebagai ajang untuk menunjukan suatu identitas yang didapatkan di dalam kehidupan bermasyarakat. 


\section{Daftar Pustaka}

Asmawati, A., Hartati, Z., \& Emawati, E. (2018). Makna Pengobatan Tradisional Badewah Suku Dayak Bagi masyarakat Muslim di Kalimantan Tengah. Jurnal Religio: Jurnal Studi Agama-Agama, 8(1), 82-115.

Bungin, B. (2003). Metode Triangulasi di dalam Analisis Data Penelitian Kualitatif. Jakarta: Kencana. Geertz, C. (1992). Tafsir Kebudayaan. Jakarta: Kanisius.

Jong, W. De. (2000). Luka-Luka Bakar : Buku Ajar Ilmu Bedah Edisi 2. Jakarta: EGC.

Layendecker, L. (1983). Tata, Perubahan, dan Ketimpangan: Suatu Pengantar Sejarah Sosiologi. Jakarta: Gramedia.

Lexy, M. (1994). Metodologi Penelitian Kualitatif. Bandung: Remaja Rosdakarya.

Pals, D. (2001). Seven Theories of Relagion. Yogyakarta: Qolam.

Reni, M. (2006). Upacara Maubek Paja pada orang Melayu Nagari Koto Rajo Kecamatan Rao Utara Kabupaten Pasaman. Skripsi. Universitas Negeri Padang.

Sugiyono, S. (2010). Metode Penelitian Kualitatif, Kuantitatif, dan $R \&$ D . Bandung: Alfabeta.

Zakaria, I. (1984). Tambo Sakti. Jakarta: Depdikbud. 